\title{
The demise of the Lutheran Theological Institute Library and Archives in retrospect Reflections of a Manuscript Librarian in Pietermaritzburg, South Africa
}

\section{Francis Garaba ${ }^{1}$}

Abstract

The closure of an information centre - be it a library, archives or a museum - should be a cause for concern for the information professional, considering that information available in these centres may be risky, particularly when there is a joint ownership which ends due to conflict. This leaves the record vulnerable, both physically and electronically. To compound the situation, the lack of a proper transition mechanism to oversee that library and archives equipment (with the information from these centres) is handed over to the new custodians of the material, for temporary storage, has far reaching consequences in terms of access and preservation. The dramatic scenes that ensued at the Lutheran Theological Institution's (LTI) Library and Archives are worth documenting for the benefit of sister institutions and for the information sector in general, particularly in situations where conflict is concerned as was the case here. The demise of LTI was an unmitigated disaster owing largely to internal dissension. Teijgeler (2006), the International Federation of Library Associations and Institutions (IFLA) (2017) and Ngulube (2018) acknowledged that like many other forms of cultural heritage, documentary works are under constant threat of destruction due to a number of reasons, and conflict was singled out as was the case at the LTI Library. However, a number of lessons can be learnt from this debacle and a few will be highlighted here. Firstly, faith-based collections (religious archives) need to be legislated like their counterparts' - public archives. Secondly, sister institutions need to ensure that both records and archives management functions are harmonised to minimise over-reliance on donors for material in the archives.

Keywords: Pietermaritzburg Cluster of Theological Libraries, collection management, Library and Information Science, professional associations, conflict, faith-based collections, catalogue, information professional, archives

\section{Introduction}

The year 2016 witnessed the demise of one of KwaZulu-Natal's (KZN) private and richest library and archival resource, the Lutheran Theological Institute (LTI) Li-

1 Dr. Francis Garaba is a Senior Lecturer at the University of KwaZulu-Natal, Information Studies Programme, School of Social Sciences. He can be contacted at garaba@ukzn.ac.za. 
brary and its adjacent Archives within. The facility was endowed with library and archival collections about the Lutheran Church from its early inception in South Africa until 2016. In addition, it also had a comprehensive collection of theological literature from other denominations in true ecumenical spirit. As a member of the Pietermaritzburg Cluster of Theological Libraries (PCTL) ${ }^{2}$, this loss of an important partner was tragic, traumatic and evoked the spirit of the Federal Theological Seminary of Southern Africa (FEDSEM) and the Evangelical Seminary of Southern Africa (ESSA) which experienced a similar fate in the KZN province in 1993 and 2011 respectively. According to Denis and Duncan (2011), FEDSEM closed its doors as a result of financial difficulties but also because of disagreements on the manner of running a theological institution in the post-apartheid era. For the Cluster, it is fortunate that ESSA has regrouped and making progress which is positive news for PCTL. In addition, its rich collection of theological resources is still intact which is positive for the Cluster, unlike what has happened to its sister institution, the ITI. This topical paper traces how this demise unfolded and the impact this had on theological education in KZN, the dispersal of the collections and lessons to be learnt particularly from a Library and Information Science (LIS) perspective.

\section{Birth of the LTI Library}

The LTI was constituted by consolidating the Umphumulo Lutheran Theological Seminary (LTS) and the Lutheran House of Studies in Pietermaritzburg (Luthos) in January 2003 (Lutheran Theological Institute n.d.). The LTI under the Southern Africa Lutheran Theological Training Trust (SALTTT) jointly administered a library and archives. The LTI was owned by a Trust, SALTTT, which was a common venture of the Evangelical Lutheran Church in Southern Africa (ELCSA) and the United Evangelical Lutheran Church in Southern Africa (UELCSA). The LTI was linked to the School of Religion, Philosophy and Classics (SRPC) at the University of KwaZulu-Natal (UKZN), Pietermaritzburg. The LTI library was a member of the Cluster of Theological Institutions together with the Catholics at St. Joseph's Theological Institute, the Methodists at Seith Mokitimi Methodist Seminary (SMMS), the Anglicans at the Anglican Diocese (AnHouse), the SRPC at UKZN, Pietermaritzburg and the Congre-

2 The Pietermaritzburg Cluster of Theological Libraries (PCTL) is an association of the libraries of the St. Josephs Theological Institute (SJTI); Cedara, the School of Religion, Philosophy and Classics (SRPC) at the University of KwaZulu-Natal (UKZN); the Congregational House of Formation (CHoF); the Anglican House of Studies (AnHoS); the Seith Mokitimi Methodist Seminary (SMSS) and the Evangelical Seminary of Southern Africa (ESSA) which could soon be re-admitted once its accreditation status has been resolved. The Cluster was established in 1989 and solemnly inaugurated in 1990 (Denis \& Duncan, 2011:160). 
gationalists at the Congregational House of Formation (CHoF). These institutions, inter alia, continue to share library and staff resources despite the demise of the LTI.

\section{The collection}

The ecclesiastical library had, as part of its collection, a comprehensive and rich documentary heritage of print and electronic resources in the form of bulletins, books, journals, magazines, etc. Kuhn (2003) recorded that the LTI collections on the Cataloguing Network in Pietermaritzburg (CATNIP) stood at 20384 . He later (2018) confirmed that this had increased to 35752 items in the catalogue without any additions since 2015. From an archival point of view, documents relating to individual staff members, students, pastors and their papers and research, as well as to institutions, associations, curricula, conferences, student bodies, applications, welfare, minutes of meetings, reports, societies, committees, records of appeal and adjudication, interoffice memos, appointment books, registers, charters, constitutions and bylaws, legal papers, deeds, articles of incorporation, agreements, financial ledgers, and various other papers pertaining to the different churches or missions were included in the files (Garaba \& Zaverdinos, 2014a). In addition, the archival repository also maintained a historical depository of denominational journals, periodicals, convention proceedings or transactions pertaining to the $\mathrm{Lu}$ theran Church in South Africa.

\section{Demise and impact on theological education}

Winkler (1989:116) noted that throughout their history, the Lutheran missions and churches have been divided in many ways. From the first mission congregations, through the formation of synods, to the present churches, there have been divisions along confessional, ethnic and racial lines. Consequently, evangelical Lutheranism has a long history of in-fighting since time immemorial and Scriba (1997:4) also attests to this fact. Winkler (1989) further noted that mirroring both the sociopolitical realities of colonial society and the wish to preserve the German culture and language on foreign soil, were thus developed out of the work of the Lutheran missionaries, two sets of congregations; one black and one white. ELCSA represents the black church, while UELCSA renamed ELCSA (N-T) represents the white church. The vision of a one united church has remained a pipe-dream and the demise of the LTI can be traced to this fragmentation as the unity only existed on paper and not in practice. It is in the failure to achieve complete unity that the roots of the political conservatism of the Lutheran churches lies (Winkler, 1989:117-118).

Consequently, the deep-seated divisions affected the governance framework in SALTTT which eventually led to the collapse of the governing body. This fragile unity 
only needed one incident for both ELCSA and UELCSA churches, as members of SALTT, to separate as had been the status quo from the onset. A large amount of money, close to R40 million, went missing in the ELCSA church which caused an uproar and impacted the running of the LTI. The media reported:

R40 million is said to have disappeared from the coffers of the Evangelical Lutheran Church in Southern Africa (ELCSA) in a development that seems to have introduced feast of fury in the house-of-god. The matter is brewing into an embarrassing scandal for the Church. The apparent disappearance of the funds is said to have condemned the Church and its student ministers into financial misery. The ELCSA General Assembly is reported to be blaming the Church's council and executive in a decision characterised as "unauthorised and reckless" while others are screaming fraud. News of the disappearance of the Church funds was reported early this week in The New Age newspaper with suggestion that the money has gone into a "dodgy offshore investment scheme". The R40 million was disinvested from an Old Mutual investment account and handed to a third party which had promised to invest the money in a better performing instrument. The decision to move the money is said to have been effected last year without proper authority by some members of the council/executive (Ujuh Reporter, 2015; See also Zululand Observer, 2016 and South African Broadcasting Corporation [SABC] News, 2016).

This state of affairs did not sit well with ELCSA (N-T) and this was the straw that broke the camel's back. The Bishop's Post Newsletter (2016), an ELCSA (N-T) publication, reported:

The financial situation of ELCSA has necessitated the Southern African Lutheran Theological Training Trust, SALTTT, to close down operations at the Lutheran Theological Institute in Pietermaritzburg. UELCSA students wishing to enrol for theological studies should contact their bishop. Currently, UELCSA has decided to recommend the University of Stellenbosch as a preferred institution for undergraduate students for the ministry. This brings to an end a 40-year relationship with the University of KwaZulu-Natal. A reflection on this will follow at a later stage (Bishop's Post, 2016).

With the break-up confirmed, UELCSA/ELCSA (N-T) proceeded to sell its portion of assets at LTI and the land has since been bought by a developer who intends to construct student accommodation and at the time of writing this article, the buildings had been razed to the ground with construction activities suspended pending a court case by Scottsville residents ${ }^{3}$. Notwithstanding, ELCSA (N-T's) Church Council Report to Synod (2017) confirmed the latest developments:

3 The Witness (2017) reported that Scottsville residents were against a planned development of accommodation for 508 students running between Golf and Carbis Roads. Construction activities had since been suspended as the residents got an order from Msunduzi Municipality's planning depart- 
With the closing of the Lutheran Theological Institute (LTI) in Pietermaritzburg, the sale of UELCSA's share of the properties and the transfer of the Southern African Theological Training Trust to ELCSA, the 42 years of involvement in Pietermaritzburg come to a sad ending. Although both UELCSA and ELCSA stated very clearly that they want to continue working together in training pastors, and Bishop Filter had been tasked by both Churches through the Southern African Theological Training Trust (SALTTT) to negotiate with Stellenbosch University, currently the Churches are going their own way. With the closure of the Lutheran Theological Institute (LTI) in Pietermaritzburg and the ending of our agreement with the University of KwaZulu Natal, UELCSA recommended to ELCSA that the properties in Pietermaritzburg be sold to avoid further escalation of costs and deterioration of assets. Eventually UELCSA only sold its portion of the LTI. In order for the sale to be finalised, UELCSA still had to carry the outstanding costs to the municipality. These were incurred by ELCSA, who was not able to pay for them (Evangelical Lutheran Church in Southern Africa (N-T) Church Council Report to Synod, 2017).

With UELCSA/ELCSA (N-T) having disposed their assets, ELCSA still have a few structures left which includes the Jubilee Flat, Landman House, the main house, the cottage and the LTI Library, the latter will now be the centre of attention. It should be pointed out from the onset that in the melee that followed the finalisation of the dispute, and thereafter, the ransacking of equipment by both churches was rampant and disorderly as each laid claim to property. The fact that library assets could have gone into wrong hands is a not a distant possibility as staff were traumatised as events unfolded and this was worsened by the lack of information as to what was really happening. The librarian was off sick for a number of months and only worked half day upon her return. In her absence, students without library qualifications and experience took over the running of the library which did not augur well professionally as security of the library collections was compromised. The author was continually updated on some of the developments, undertook personal visits at times and witnessed first-hand the drama as it unfolded. The Library structure is still intact but now an empty shell bereft of material, and the library collection was transferred to a commercial records centre for storage with shelves, uprights

ment that only permission to demolish the building could go ahead and not the excavations. See also The Witness, 2017. Residents object to 508 bed student accommodation. Available: https://www. pressreader.com/south-africa/the witness/20171130/281560881112858 (Accessed 5 January 2018). In an email correspondence on this matter on 10 October 2018, the Msunduzi Municipality reported that the application in question had not yet been finalised as they were still at the report writing stage. They promised they would let me know of the outcome as soon as the resolution was taken (Shinga, 2018). 
andbraces later disassembled and disposed of. It is most likely that the archival collection was repossessed by the depositors from the white ELCSS (N-T) Church as the provenance of the material is traced to them and the bulk of the collection in the archives was due to their benevolence (Garaba \& Zaverdinos, 2014a) ${ }^{4}$.

The closure of LTI had many ramifications, with regards to theological education in KZN. Firstly, the primary material is gone which students used in their scholarly work and these are now dark archives defined as a collection of materials "preserved" for future use but with no current access (Pearce-Moses, 2005). Secondly, the loss of the library collection is disappointing in terms of sources for theological students within PCTL. This literary genocide is a consequence of political struggle within the Lutheran Church which eventually led to the dissolution and dismantling of the library, similar to the 16th and 19th century European monasteries (Raven, 2004:29). Thirdly, the closure of LTI signalled the end of the partnership with UKZN and other PCTL members in terms of the sharing of resources and expertise, as well as the collegiality provided by the LTI which helped in the training of pastors within the Cluster. Fourthly, theological training for UELCSA (N-T's) Lutherans has now shifted base to the Western Cape at the University of Stellenbosch and the ELCSA (N-T) Church Council Report to Synod (2017) reiterated that the University of Stellenbosch is now the recommended University for those who wish to study theology towards full-time ministry. ELCSA's training plans are unknown and reviving the LTS site, where the seminary originated before the relocation to LTI, and pursuing the once mooted dream of a Lutheran University of Southern Africa with the help of the Lutheran World Federation may solve the problem.

\section{Lessons to be learnt from a LIS perspective}

i. The need to have a defined collecting policy cannot be emphasised for any information centre. Due to the lack of archival policy, however, LTS as it was known then, collected denominational resources unknowingly, by accident (Garaba \& Zaverdinos, 2014b) and relied heavily on donor individuals. Consequently, donors could deposit and recall material - at will - which was problematic for the ITI Archives since the bulk of the material was copyrighted to the donors as it was their intellectual property. The terms and conditions under which archival material should be kept needs to be spelt out from the onset and any violation of the negotiated arrangements must be subject to legal recourse.

4 Email reminders to the student who was last in charge of the collections to extract this information had not borne fruition. Information on the list of items transported to a commercial storage centre, the whereabouts of archives in both electronic and physical form, library catalogue records and equipment, etc., merited verification hence this speculation is in view of the acrimonious divorce. 
To this day, the author continues to receive emails from patrons inquiring about access to the Lutheran Archives.

ii. Catalogue records in the Cataloguing Network in Pietermaritzburg (CATNIP) database are still showing LTI library records with the prefix ELC (Evangelical Lutheran Church) which is misleading in view of the demise of the library and the fact that these are no longer accessible. The database or information provided on the system informing the user about the current status of the resource needs to be updated. If the memorandum of agreement in the PCTL was binding, in terms of intellectual rights, access should have continued for the sake of patrons irrespective of the collapse of LTI. Wherever the material is, patrons have the right to access it as per the memorandum of agreement using InterLibrary Loan agreements and also in conformity with the Promotion of Access to Information Act (2002)

iii. While acknowledging that the situation at the LTI was rather complex in view of the infighting, management needed to have a sympathetic ear to the plight of Library and archival resources to allow the safe-guarding of this material for the sake of posterity as this theological heritage is irreplaceable. Where libraries and archives face imminent closure, the transition arrangements should ensure that the record which is sacrosanct to our profession is protected and mechanisms put in place as to where the collection will be housed, and continued access provided. There should be ongoing collection management entrusted to commercial storage vendors without the input of ill-advised professionals who are stewarding the collection. Management should take the blame for this oversight and need to put differences aside for the sake of this documentary heritage. In any case, how long the material will be escrowed at its new location needs to be resolved urgently, considering the unsustainability of this option in view of storage costs. For the record, book collections of the prestigious FEDSEM library remained in unused boxes after its demise in 1993 (Denis \& Duncan, 2011:269) and this could end up being the case with the LTI library collections. Seemingly, evidence in history has shown that where such appalling mistakes are made to break-up libraries, the reconstruction has often proven difficult, similar to what happened to monastic libraries in 18th century Austria (Buchmayr, 2004:157).

In addition, staff needed to be appraised regularly with the ongoing developments to avoid the rumour mill as this entails disclosure of information that the employee is lawfully entitled to and support mechanisms for counselling provided in line with the Labour Relations Act (Republic of South Africa Labour Relations Amendment Act, 2002). The author would argue that the demise of the library was due to gross mismanagement and irresponsibility, and the need for transparency and account- 
ability cannot be overemphasised. The culprits therefore need to be brought to book as this man-made disaster has subsequently led to the collapse of an important theological resource in KZN and the loss of documentary heritage for the country. As poignantly noted by Teijgeler (2006:133), man-made disasters can even outdo natural disasters in the detrimental effects of our collective memory of the past. Statements of condemnation by professional associations like the Library and Information Association of South Africa (LIASA) and the South African Society of Archivists (SASA) would have sufficed in solidarity with staff and for the sake of libraries and archives. For the record, LIASA regularly issues statements when libraries are destroyed but its deafening silence on the ITI Library appears hypocritical. Evidently, it should not be about size but principle.

\section{Professional ethics}

Ethics is about the do's and don'ts in professional practice. Information professionals usually find themselves in a dilemma when the values between employer and employee are in conflict as was the case with LTI. The months leading to the closure were difficult at LTI in view of the fact that the situation was unconducive to render information services. However, the remaining librarian at LTI was an information hero as Dick (2014) argues - she continued providing access to information in trying times, considering that there was a black-out on information about the developments which took its toll on the well-being of staff. The unenviable circumstances at LTI further explain why she does not know where the archives were taken to (Zaverdinos, 2018), but she deserves special commendation for holding the fort by allowing access to information for the remaining students to complete their pastoral training at LTI and degrees for those studying at UKZN, as well as the Cluster at large. Indeed, there are many professionals who struggle daily to safeguard all that the human mind produces, both tangible and intangible products (Teijgeler, 2006:133).

\section{Records and archives management}

A lesson for the remaining Cluster partners with faith-based archives is the need to ensure that there is a harmonious relationship between records and archives management functions at their institution, to ensure that records should not only be properly managed for business continuity but that a healthy record gets into the archives. A continuum of care needs to be provided for this Christian heritage from the point of creation until retirement of those records with enduring value (Garaba, $2013 ; 2015)$. The establishment of a records management programme, which will include a full-scale inventory, thereby leading to the development of a records disposition schedule, is recommended to ensure that the institute's corporate memory is jealously safe-guarded to minimise over-reliance on donors as was the case with 
the LTI Archives. In addition, recording oral reminiscences of important figures in the Church and encouraging donation of papers by them will help in this regard and in attempts to refigure the archive to reflect a post-apartheid South Africa. Assuming the archival collection could have been withdrawn by the depositors, this still needs to be verified and accounted for as the records represent an important epoch in Lutheran history and is a gap which will be difficult to fill if their whereabouts remain unknown. Archives will remain with footprints of human civilisation and we need them to retrace our past, promote transparency and accountability.

\section{Legislation}

The lethargic legislation for private archives in as far as this applies to faith-based collections is once again brought into the spotlight. Faith-based collections need to be legislated like their counterparts' public archives so that they are available when citizens request to have access to them in terms of the law (Garaba, 2014). The framework to deal with records created by private bodies needs a rethink to avoid the LTI scenario. In the United Kingdom, for instance, both public and private organisations are required to comply with the Data Protection Act in conformity with FOI legislation. Merely listing private collections on the National Archives and Records Service of South Africa (NARSSA) collection database as is currently the case is cosmetic and needs to be re-examined by taking a pragmatic oriented approach in overseeing their management and protection.

\section{Conclusion}

This paper reminisced on the demise of the LTI Library and Archives facility which heralded a sad chapter in the history of the PCTL and the information sector in South Africa at large. How such a colossus, in terms of theological resources, disintegrated is evidence of the destruction that can be wrought by mankind when there is conflict. Indeed, as Knuth (2015:306) averred, biblioclasm or libricide has occurred when the social and political environment is conflict-ridden and when social groups become polarised and reactive. However, it is gratifying to note that in the midst of this man-made disaster, a gamut of lessons can be drawn for use by sister institutions in the PCTL and the information sector in general. Policies, intellectual issues in terms of access and preservation arrangements, managerial gaffe, professional ethics in terms of working conditions where there is conflict, the need to harmonise records and archives management practice for that feeder or conduit for the archives, the need for a transition mechanism whenever disputes arise leading to the closure of an information centre, and the need for protection of information subject to legislative revisions where private archives are concerned, are some of the highlighted issues that need to be considered in future conflict 
situations in the information sector. The LIS sector in South Africa should emerge richer, stronger and well informed to avert such scenarios in future, similar to what happened to the LTI, as the situation could have been better handled. The LIS sector needs more information heroes like Annalise Zaverdinos who in the face of such adversity responded to the call of duty, remained steadfast at the expense of her health and deserved better professionally in terms of treatment.

\section{Dedication}

This paper is dedicated to all stakeholders at the ITI, deceased and living, whose footprints left an indelible mark on the history of LTI - their beautiful memories at this institution will always be cherished. Special gratitude is reserved for Rev. Scriba for his love and passion for archives and to the founder of LTI, the late Professor Wittenberg, both for their immense contribution to the infrastructural development of LTI and to the UKZN's School of Religion as pioneers in curriculum development. The late Dr. Msomi and the late Bishop Manas Buthelezi, two of the greatest African theologians of the Lutheran Church also deserve special mention with their willingness to donate manuscripts and have their reminiscences captured orally in an attempt to initiate the re-figuring of the Lutheran Archives which was sadly overtaken by these tragic events. Lastly, Annalise Zaverdinos was the last librarian standing during these upheavals and her loyalty and dedication to duty qualifies her as a true information professional and hero.

\section{References}

Bishop's Post Newsletter. February-March 2016. Available: http://www.elcsant.org.za/uploads/8/8/3/9/8839616/bishopspost_febmar16_english.pdf [Accessed 5 January 2018].

Buchmayr, F. 2004. Secularization and monastic libraries in Austria. In: Raven, J. (ed.). Lost libraries: the destruction of great book collections since antiquity. Houndmills, Basingstoke, Hampshire; New York: Palgrave Macmillan. pp. 145-162.

Denis, P. and Duncan, G.A. 2011. The native school that caused all the trouble: a bistory of the Federal Theological Seminary of Southern Africa. Dorpspruit: Cluster Publications.

Dick, A.L. 2014. Information heroes. Information Development, 30(3), 197-199. Evangelical Lutheran Church in Southern Africa (N-T). 2017. Church Council Report to Synod. Available: www.elcsant.org.za/uploads/8/8/3/9/.../church_council_report_ to_synod_2017.pdf [Accessed 5 January 2018].

Garaba, F. 2013. Collection stewardship constrained by resources: The management of religious archives in Pietermaritzburg, KwaZulu-Natal region. Verbum et Ecclesia, 34(1), Art. \#788:1-11. 
Garaba, F. 2014. Religious archives in the East and Southern Africa Regional Branch of the International Council on Archives (ESARBICA) region: Their importance and the need for a national framework. ESARBICA Journal: Journal of the Eastern and Southern Africa Regional Branch of the International Council on Archives, 33: 46-56.

Garaba, F. and Zaverdinos, A. 2014a. The Evangelical-Lutheran Church in South Africa: An introduction to its archival resources held at the Lutheran Theological Institute (ITI) Library, and the challenges facing this archive (Part One). Missionalia: Southern African Journal of Missiology, 42(1-2), 5-28.

Garaba, F. and Zaverdinos, A. 2014b. The Evangelical-Lutheran Church in South Africa: An introduction to its archival resources held at the Lutheran Theological Institute (LTI) Library, and the challenges facing this archive (Part Two). Missionalia: Southern African Journal of Missiology, 42(1-2), 29-37.

Garaba, F. 2015. Disembodied archives: The disconnectedness of records and archives management practices within the Pietermaritzburg Cluster of Theological Libraries, KwaZulu-Natal, South Africa. Verbum et Ecclesia, 36(1), Art. \#1357:1-20. International Federation of Library Associations and Institutions. 2017. Libraries safeguarding cultural heritage. Available: https://www.ifla.org/files/assets/pac/Documents/librariessafeguarding-cultural-heritage.pdf [Accessed 3 January 2018].

Knuth, R. 2015. Understanding modern biblioclasm. In: Cloonan, M.V. (ed). Preserving our heritage: perspectives from antiquity to the digital heritage. London: Facet Publishing. pp. 297-308.

Kuhn, R. 2003. One million mark. University of Natal Library Bulletin, 354. Available: http://library.ukzn.ac.za/pdfs/Pietermaritzburg\%20Library\%20Bulletin/354Jul2003. pdf [Accessed 5 January 2018].

Kuhn, R. 2018. Email letter to author on 10 January. Lutheran Theological Institute. (n.d.). Available: http://ti.ukzn.ac.za/Homepage.aspx [Accessed 5 January 2018].

Ngulube, P. 2018. Preface. In: Ngulube, P. (ed.). Handbook of research on beritage management and preservation. Hershey, PA: IGI Global. pp.xx-xxiii.

Pearce-Moses, R. 2005. Dark archives. Glossary of archival and records terminology. Available: https://www2.archivists.org/glossary/terms/d/dark-archives [Accessed 5 January 2018].

Raven, J. 2004. Introduction: the resonances of loss. In: Raven, J. (ed.). Lost libraries: the destruction of great book collections since antiquity. Houndmills, Basingstoke, Hampshire; New York: Palgrave Macmillan. pp. 1-40. Republic of South Africa. Labour Relations Amendment Act, 2002. Available: http://www.labour.gov.za/DOL/downloads/ legislation/acts/labour-relations/amendments/Amendment\%20\%20Labour\%20Relations\%20Act\%202002.pdf [Accessed 5 January 2018].

Republic of South Africa. 2000. Promotion of Access to Information Act, 2000. Available: http://www.justice.gov.za/legislation/acts/2000-002.pdf [Accessed 5 January 2018].

Scriba, G. 1997. The growth of Lutheran churches in Southern Africa. Pietermaritzburg: Luthos Publications.

Shinga, Z. 2018. Email letter to author on 9 October. South African Broadcasting Corporation (SABC). 2016. Church invests about R40-million in a 'Ponzi-type' scheme. Available: https://www.youtube.com/watch?v=0RTTwG0sXC4 [Accessed 5 January 2018]. 
Teijgeler, R. 2006. Preserving cultural heritage in times of conflict. In: Gorman, G.E. and Shep, S.J. (eds). Preservation management for libraries, archives and museums. London: Facet Publishing. pp.133-165.

The Witness. 2017. Uproar at student res plans. Available: https://www.news24.com/SouthAfrica/News/uproar-at-student-res-plans-20170707 [Accessed 5 January 2018].

Ujuh Reporter. 2015. Missing R40m raise tempers in the Lutheran Church. Available: https://www.ujuh.co.za/missing-r40m-raise-tempers-in-the-lutheran-church-in-southern-africa/ [Accessed 5 January 2018].

Winkler, H.E. 1989. The divided roots of Lutheranism in South Africa: a critical overview of the social history of the German-speaking Lutheran missions and the churches originating from their work in South Africa. Master of Arts thesis. Department of Religious Studies. University of Cape Town.

Zaverdinos, A. 2018. Email letter to author on 2 January.

Zululand Observer. 2016. Mystery over Lutheran Church's missing R40-million. Available: https://zululandobserver.co.za/128156/mystery-over-lutheran-churchs-missing-r40million/ [Accessed 5 January 2018]. 